\title{
EARLY NEONATAL OUTCOMES IN PATIENTS WITH LATE PRETERM BIRTH
}

\author{
Ahmet KARATAS ${ }^{1}$, Mustafa ALBAYRAK ${ }^{2}$, Fatih KESKIN ${ }^{2}$, Ismail BIYIK ${ }^{3}$, Mesut OKUR ${ }^{4}$, \\ Cemalettin GUNES ${ }^{4}$, Seyit Ali KOSE 5
}

\author{
$\mathbf{1}$ Department of Obstetrics and Gynecology, Abant Izzet Baysal University, School of Medicine, Bolu, Turkey \\ 2 Department of Obstetrics and Gynecology, Duzce University, School of Medicine, Duzce, Turkey \\ 3 Department of Obstetrics and Gynecology, Karacabey State Hospital, Bursa, Turkey \\ ${ }^{4}$ Department of Pediatrics, Duzce University, School of Medicine, Duzce, Turkey \\ 5 Department of Obstetrics and Gynecology, Suleyman Demirel University, School of Medicine, Isparta, Turkey
}

\section{SUMMARY}

Objective: Preterm deliveries increased in many countries in recent years. However, despite fetal lung maturity, substantial neonatal morbidity may occur even after 34 weeks of gestation. The aim of this study was to evaluate neonatal morbidity and mortality in women with late preterm births.

Design: Retrospective.

Setting: Duzce University School of Medicine, Departments of Obstetrics and Gynecology and Pediatri Clinics.

Patients: Medical records of 291 pregnant women and newborns born between the 340/7-36 $6 / 7$ weeks of gestation were reviewed.

Interventions: The whole population is first divided into two groups as depending on the presence of PPROM or not; and then also divided into-three groups based on the gestational age at delivery as 340/7-346/7 week (Group 1), 350/7. $35^{6 / 7}$ week (Group 2), and 360/7-366/7 week (Group 3).

Main outcome measures: Groups were compared with respect to neonatal complications related to prematurity, and early membrane rupture.

Results: Of the 291 neonates included in the study, 85 were delivered preterm due to PPROM, 206 were non-PPROM group, and 76 were in Group 1, 108 were in Group 2, and 107 were in Group 3. Sepsis rate was higher in Group 1 and 2 compared to Group 3 ( $p=0.016, p=0.029)$. NICU stay period was longer in Group 1 and Group 2 than group 3 ( $p=0.028, p=0.015$ respectively). Newborns in Group 1 had significantly longer hospital stay than Group 3 ( $p=0.010)$, and total hospital stay period were significantly higher in newborns with sepsis.

Conclusions: The late-preterm infants especially in earlier weeks represent a significantly higher risk category for neonatal complications, and they have a significantly longer NICU and hospital stay period.

Key words: late preterm birth, preterm premature membrane rupture, neonatal outcomes

Journal of Turkish Society of Obstetrics and Gynecology, (J Turk Soc Obstet Gynecol), 2013; Vol: 10, Issue: 3, Pages: 165- 72

Address for Correspondence: Dr. Ahmet Karataş. Abant İzzet Baysal Üniversitesi Tıp Fakültesi, Kadın Hastalıkları ve Doğum Anabilim Dalı, Bolu Phone: + 90 (374) 2534656 e-mail: akaratas1973@hotmail.com

Received: 07 April 2013, revised:10 June 2013, accepted: 10 June 2013, online publication: 11 June 2013 


\section{GEÇPRETERM DOĞUM OLGULARINDA ERKEN NEONATAL SONUQ̧LAR}

\section{ÖZET}

Amaç: Preterm doğumlar son zamanlarda birçok ülkede artış göstermiştir. Fetal akciğerin gelişmiş olmasına rağmen, 34. gebelik haftasından sonra bile ciddi yenidoğan morbiditesi meydana gelebilir. Bu çalışmanın amacı, geç preterm doğum olgularında neonatal morbidite ve mortaliteyi araştırmaktır.

Planlama: Retrospektif.

Ortam: Düzce Üniversitesi Tıp Fakültesi, Kadın Hastalıkları ve Doğum, Pediyatri Klinikleri.

Hastalar: 340/7-366/7 gebelik haftasında doğum yapan 291 gebe kadın ve yenidoğanlar incelendi.

Girişim: Çalışmaya dahil edilen olgular PPROM varlı̆̆ ya da yokluğuna göre öncelikle ikiye ayrıldi. Daha sonra gruplar, tekrar gebelik haftasına göre kendi içlerinde, (340/7-346/7 hafta olanlar, grup 1; 350/7-356/7 hafta olanlar, grup 2; 36 $0 / 7-36^{6 / 7}$ hafta olanlar, grup 3) üçe ayrldd.

Değerlendirme parametreleri: Gruplar prematürite ve erken membran rüptürü ile ilişkili yenidoğan komplikasyonlarl aç ısından karşılaştırıldı.

Sonuç: Çalışmaya dahil edilen ikiyüz doksanbir olgunun 85'i PPROM nedeniyle erken doğum yapmıştı. 206'sı PPROM olmayan gruptaydl, ve 76's 1.grup, 108'i 2. grup, 107'si de 3.grupta yer aldı. Sepsis orani, birinci ve ikinci grupta üçüncü gruba göre daha yüksekti ( $p=0.016$, $p=0.029)$. Yenidoğan yoğunbakım ünitesinde (YDYB) kalış süresi 3. gruba oranla, 1. ve 2.grupta daha yüksekti (strastyla $p=0.028, p=0.015$ ). Birinci gruptaki yenidoğanlar, üçüncü gruptakilere göre anlamlı olarak daha uzun hastanede kalıș süresine sahipti (p=0.010), ve toplam hastanede kalış süresi sepsisli yenidoğanlarda anlamlı olarak daha yüksekti.

Yorum: Özellikle daha erken gebelik haftalarında olan, geç preterm yenidoğanlar, yenidoğan komplikasyonları iç in anlamlı olarak daha fazla risklidirler, ve anlamlı olarak yenidoğan yoğun bakimda ve hastanede daha uzun kallş süresine sahiptir.

Anahtar kelimeler: geç preterm doğum; preterm erken membran rüptürü; yenidoğan sonuçlarl

Türk Jinekoloji ve Obstetrik Derneği Dergisi, (J Turk Soc Obstet Gynecol), 2013; Cilt: 10, Sayl: 3, Sayfa: $165-72$

\section{INTRODUCTION}

Prematurity is the leading cause of neonatal morbidity and mortality ${ }^{(1)}$. Preterm delivery is described as the birth on or before the $37^{\text {th }}$ weeks of gestation following the onset of the mother's last menstrual period $(2,3)$. Late-preterm birth is defined as birth between the 340/7 and $36^{6 / 7}$ weeks of gestation ${ }^{(4)}$. Up to $60-70 \%$ of these preterm births occurred between the 34-36 weeks' of gestation indicating that late preterm births form a substantial proportion of the preterm births ${ }^{(5)}$. Data from the United States showed that the rate of late preterm deliveries rose by $20 \%$, from $6.8 \%$ to $8.1 \%$, between 1990 and 2006(6). Late preterm newborns, although they are not evaluated in high risk category, have increased risk of short and long term morbidity and mortality, and they are reported to constitute an important community problem(7).

Preterm PROM is associated with increased rates of neonatal and maternal infection and is responsible for nearly one-third of these pre-term deliveries in high- income countries ${ }^{(8)}$. Although a more or less consensus exists on the management of preterm labor between 34 and 37 weeks due to PPROM where a higher risk of chorioamnionitis for the mother and the fetus exists (911), substantial neonatal morbidity may occur even after 34 weeks of gestation despite lung maturity ${ }^{(12)}$.

The aim of this study was to analyze late preterm delivery and compare the early neonatal morbidity and mortality based on the gestational age weeks and presence of PPROM. As far as we know this is the first study on this issue in Turkey.

\section{MATERIALS AND METHODS}

This study was carried out in the Departments of Obstetrics and Gynecology and Neonatology of Duzce University School of Medicine. We retrospectively collected the antepartum and intrapartum records of 291 singleton pregnancies and neonatal outcomes delivered between 34 - 366/7 weeks of gestation, 
spontaneous or indicated, from January 2009 to December 2011. The study protocol was approved by the University Non-invasive Human Research Ethics Committee.

Demographic characteristics including maternal age, pre-existing maternal medical problems such as hypertensive disorders, heart diseases, renal disease, infections such as chorioamnionitis or pyelonephritis, and other pregnancy-specific complications gestational age at delivery, birth weight, vaginal and cesarean delivery rates were recorded. Diagnosis of preterm PROM was made in the presence of leakage of clear fluid from the cervical channel or accumulation of fluid in the posterior fornix during dry speculum examination, and a positive nitrazine and ferning test or a positive placental alpha microglobulin-1 (PAMG1) (Amniosure, International LLC, USA) ${ }^{(13)}$. A single dose of $12 \mathrm{mg}$ betamethasone ( $1 \mathrm{ml} /$ ampul Chronodose Celestone, Schering-Plough) was injected to 25 pregnant women those excluded maternal infection in both groups.

Neonatal outcome data related to prematurity included transient tachypnea of the newborn (TTN), apnea of prematurity, respiratory distress syndrome (RDS), neonatal sepsis, hypoglycemia, jaundice, total number of phototherapy days and the neonatal intensive care unit (NICU) stay of neonate, total length of the hospital stay, and neonatal mortality. Diagnostic criteria for each neonatal morbidity were set by neonatologists as follows: (1) apnea of prematurity: prolonged respiratory pause (20 seconds or longer) accompanied by cyanosis, pallor or bradycardia; (2) TTN: clinical and radiographic features identified during the first hours of life, followed by characteristic resolution during the subsequent 24 48 hours; (3) hypoglycemia: blood glucose level below $40 \mathrm{mg} / \mathrm{dL}$; (4) hyperbilirubinemia based on gestational week and birth weight; (5) neonatal sepsis: positive blood culture and clinical manifestations.

The discharge criteria for preterm infants included satisfactory suction upon breast-feeding assessed by experienced nursing personnel accompanied by adequate weight gain.

The first aim of this study is to evaluate the early neonatal morbidity in late preterm newborns, and the second one is to evaluate the impact of membrane rupture to neonatal morbidity.

\section{Statistical analysis}

The Statistical Package for Social Sciences (SPSS for Windows Version 19.00, Chicago, IL, USA) program was used for assessment of the results. The distribution of data analyzed using the Shapiro-Wilks test according to which suitable parametric and non-parametric tests were selected. The parametric data are given as arithmetic means \pm standard deviation (SD) and nonparametric data are given as median (minimummaximum). Pearson chi-square test was used to compare categorical variables. When there were more than two groups, one way ANOVA and Kruskall Wallis tests were used. In the comparison of the groups, the univariate variance analysis was used in variables with normal distribution (Oneway-ANOVA test), while the Post Hoc test (Tukey-HSD) and Bonferroni correction was used for multiple comparisons $\left(\alpha^{*}=0.05 / 3=0.017\right.$ ), respectively. Mann Whitney U test was used in cases showing a statistical difference between the two groups. A $p$ value of $<0.05$ was regarded as significant.

\section{RESULTS}

Late preterm birth rate was $6.7 \%(291 / 4301)$ in threeyears period. Of the 291 neonates included in the study, 85(2\%) were delivered with PPROM, and 206(4.7\%) without PPROM.

Totally, 80 women presented with some sort of complicated obstetric maternal problem besides the preterm delivery in both groups. Preeclampsia was the most frequent condition and was diagnosed in 65 women in total. Only preeclampsia, maternal infection and antibiotherapy administration rate were statistically different between nonPPROM and PPROM groups (Table I). Maternal infection was diagnosed in 12 women, four women with chorioamnionitis and eight with pyelonephritis and antibiotherapy rates were higher in PPROM compared to non-PPROM group as expected.

Caesarean section rate was higher in non-PPROM group compared to PPROM group (65.5\% vs. $35.3 \%$, $\mathrm{p}=0.001$ ) (Table II). Considering neonatal complications, neonates sepsis rate were similar between groups: 10 $(11.7 \%)$ in PPROM group and $15(7.2 \%)$ in nonPPROM group $(\mathrm{p}=0.215)$. Other parameters related to morbidity including Neonatal Intensive Care Unit (NICU) and total hospital stay periods were also statistically similar. 
Table I: Demographic characteristics and systemic problems of women with and without premature rupture of membranes.

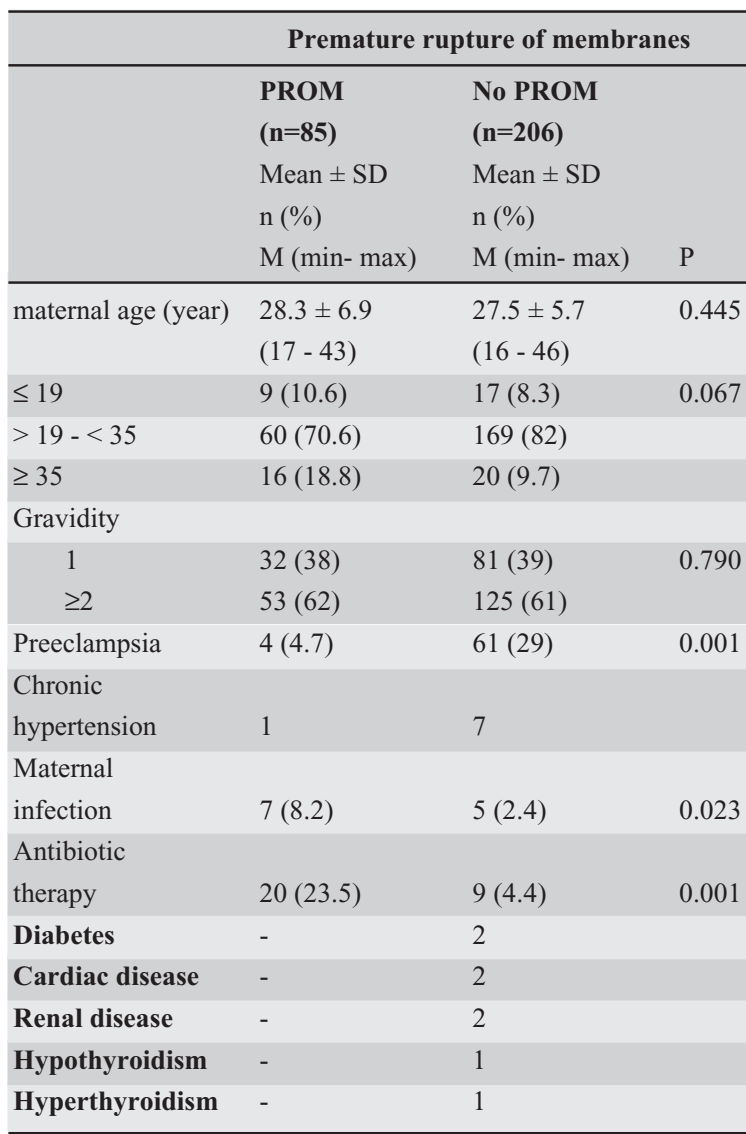

Mean \pm SD: Mean \pm standart deviation, $\boldsymbol{n}(\%):$ number (percentage),

$\boldsymbol{M}(\min -\max ):$ Median (minimum- maximum)

When we stratified the whole group based on the gestational age at delivery, $76(26 \%)$ were at 340/7 $34^{6 / 7}$ (Group 1), 108 (37\%) were at 350/7-356/7 (Group 2), and 107 (36\%) were at 360/7-36 6/7 (Group 3) gestational weeks (Table III). There were no differences in maternal age, gravidity patterns, rates of preeclampsia, maternal diabetes, and chorioamnionitis between the groups. However, rupture of membrane was significantly higher only in Group 2 than the Group 3 (for Group 2 vs. Group 3, P=0.013). Caesarean delivery rate was similar among groups $(61.8 \%, 51.9 \%$, $57.9 \%$, respectively). RDS and necrotising enterocolitis (NEC) rate did not differ among the groups. Among the 291 neonates there was no mortality and none had intraventricular haemorrhage. Sepsis rate was higher in Group 1 and 2 with 11 newborns in each group compared to Group 3 in which three newborns were detected with sepsis $(14.5 \%, 10 \%$ and $2.8 \%$, respectively; $\mathrm{p}=0.016, \mathrm{p}=0.029$ ). Also, the number of
Table II: Birth and neonatal morbidity data in those women with and without premature rupture of membranes.

\begin{tabular}{|c|c|c|c|}
\hline & \multicolumn{3}{|c|}{ Premature rupture of membranes } \\
\hline & $\begin{array}{l}\text { PROM } \\
(\mathbf{n}=\mathbf{8 5}) \\
\text { Mean } \pm \text { SD } \\
\mathrm{n}(\%)\end{array}$ & $\begin{array}{l}\text { No PROM } \\
(\mathbf{n}=\mathbf{2 0 6}) \\
\text { Mean } \pm \text { SD } \\
\mathrm{n}(\%)\end{array}$ & \\
\hline & M (min- max) & $\mathrm{M}(\min -\max )$ & $\mathrm{P}$ \\
\hline Applicant week & $35.2 \pm 0.8$ & $35.2 \pm 0.9$ & 0.584 \\
\hline Steroid & $6(7.1)$ & $19(9.2)$ & 0.549 \\
\hline $\begin{array}{l}\text { Gestational age } \\
\text { (week) }\end{array}$ & $35.2 \pm 0.8$ & $35.4 \pm 0.85$ & 0.152 \\
\hline Cesarean rate & $30(35.3)$ & $135(65.5)$ & 0.001 \\
\hline Birth weight (g) & $2460 \pm 265$ & $2400 \pm 304$ & 0.194 \\
\hline Transient tachypnea & $4(4.7)$ & $12(5.8)$ & 0.703 \\
\hline $\begin{array}{l}\text { Respiratory distress } \\
\text { syndrome }\end{array}$ & $2(2.3)$ & $6(2.9)$ & 0.791 \\
\hline Pneumonia & $3(3.5)$ & $4(1.9)$ & 0.422 \\
\hline Hypoglycemia & $7(8.2)$ & $20(9.7)$ & 0.694 \\
\hline Sepsis & $10(11.7)$ & $15(7.2)$ & 0.215 \\
\hline Necrotizing enterocolitis & $1(1.2)$ & $1(0.5)$ & 0.516 \\
\hline Phototherapy & $16(18.8)$ & $40(19.4)$ & 0.907 \\
\hline Phototherapy (day) & $2(1-7)$ & $2(1-7)$ & 0.975 \\
\hline $\begin{array}{l}\text { NICU need } \\
\text { newborn (n) }\end{array}$ & $26(30.5)$ & $57(28)$ & 0.616 \\
\hline Stay in NICU (day) & $5(2-23)$ & $6(1-18)$ & 0.603 \\
\hline Stay in hospital (day) & $8(2-30)$ & $7(2-28)$ & 0.580 \\
\hline Ventilator use & 0 & 0 & \\
\hline $\begin{array}{l}\text { Intraventricular } \\
\text { hemorrhage }\end{array}$ & 0 & 0 & \\
\hline
\end{tabular}

Mean \pm SD: Mean \pm standart deviation, $\boldsymbol{n}(\%)$ : number (percentage),

$M(\min$ - max): Median (minimum- maximum), NICU: Neonatal Intensive Care Unit.

newborns needing NICU was higher in Group 1 (32, $42 \%)$ and Group $2(38,35 \%)$ compared to Group 3 $(13,12 \%)(\mathrm{p}<0.001)$. Additionally, NICU stay period was longer in Group 1 (6 days, mean:1-13) and Group 2 (6 days, mean: 3 -13\%) compared to Group 3 (4.2 \pm 2.1 days) ( $\mathrm{p}=0.028$ for Group 1 and $3, \mathrm{p}=0.015$ for Group 2 and 3). When total hospital stay was evaluated, newborns in Group 1 had significantly longer hospital stay than Group $3(\mathrm{p}=0.010)$. Newborn sepsis, maternal infection and antibiotherapy rates were similar among the groups. However, vaginal birth rate ( $59 \%$ vs. $36 \%$ respectively; $\mathrm{p}=0.029)$, RDS rate $(12 \%$ vs. $2 \%$ respectively; $\mathrm{p}=0.003$ ) and total hospital stay period (11 vs. 6 days respectively; $\mathrm{p}<0.001$ ) were significantly higher in newborns with sepsis compared to newborns without sepsis. 
Table III: Maternal demographic characteristics, birth and neonatal morbidity data according to the week of delivery.

\begin{tabular}{|c|c|c|c|c|}
\hline & \multicolumn{3}{|c|}{ Delivery week } & \multirow[b]{6}{*}{$\mathrm{P}$} \\
\hline & $34^{0 / 7}-34^{6 / 7}$ & $35^{0 / 7}-35^{6 / 7}$ & $36^{0 / 7}-36^{6 / 7}$ & \\
\hline & $n=76(\% 26)$ & $n=108(\% 37)$ & $\mathrm{n}=107(\% 36)$ & \\
\hline & Mean \pm SD & Mean \pm SD & Mean $\pm \mathrm{SD}$ & \\
\hline & $\mathrm{n}(\%)$ & n $(\%)$ & n $(\%)$ & \\
\hline & $\mathrm{M}(\min -\max )$ & M (min - max) & $M(\min -\max )$ & \\
\hline \multirow[t]{2}{*}{ Maternal age (year) } & $28 \pm 5.4$ & $27.8 \pm 6.3$ & $27.5 \pm 6.4$ & \multirow[t]{2}{*}{0.782} \\
\hline & $(17-42)$ & $(17-46)$ & $(16-41)$ & \\
\hline$\leq 19$ & $4(5.3)$ & $9(8.3)$ & $13(12.1)$ & \multirow[t]{3}{*}{0.386} \\
\hline$>19-<35$ & $64(84.2)$ & $87(80.6)$ & 78 (72.9) & \\
\hline$\geq 35$ & $8(10.5)$ & $12(11.1)$ & $16(15)$ & \\
\hline \multicolumn{5}{|l|}{ Gravidity } \\
\hline 1 & $26(34.2)$ & $40(37)$ & $47(44)$ & \multirow[t]{2}{*}{0.368} \\
\hline$\geq 2$ & $50(65.8)$ & $68(63)$ & $60(56.1)$ & \\
\hline Preeclampsia & $16(21.1)$ & $18(16.7)$ & $31(29)$ & 0.091 \\
\hline Maternal infection & $1(1.3)$ & $5(4.6)$ & $6(5.6)$ & 0.336 \\
\hline Antibiotic therapy & $6(7.9)$ & $16(14.8)$ & $7(6.5)$ & 0.101 \\
\hline \multirow[t]{3}{*}{ Rupture of membrance } & $22(29)$ & $40(37)$ & $23(21)$ & 0.043 \\
\hline & & & & ${ }^{b} 0.044$ \\
\hline & & & & ${ }^{\mathrm{c}} 0.013$ \\
\hline \multirow[t]{3}{*}{ Steroid use } & $12(15.8)$ & $6(5.6)$ & $7(6.5)$ & 0.032 \\
\hline & & & & a 0.021 \\
\hline & & & & ${ }^{\mathrm{b}} 0.043$ \\
\hline Cesarean rate & $47(61.8)$ & $56(51.9)$ & $62(57.9)$ & 0.383 \\
\hline \multirow[t]{4}{*}{ Birth weight (g) } & $2270 \pm 321$ & $2415 \pm 285$ & $2520 \pm 234$ & $<0.001$ \\
\hline & & & & a 0.003 \\
\hline & & & & $\mathrm{b}<0.001$ \\
\hline & & & & $\mathrm{c} 0.021$ \\
\hline Transient tachypnea & $5(6.6)$ & $8(7.4)$ & $3(2.8)$ & 0.298 \\
\hline \multirow[t]{3}{*}{ Sepsis } & $11(14.5)$ & $11(10)$ & $3(2.8)$ & 0.016 \\
\hline & & & & ${ }^{b} 0.016$ \\
\hline & & & & c 0.029 \\
\hline Necrotizing enterocolitis & $1(1.3)$ & $1(0.9)$ & 0 & 0.530 \\
\hline Respiratory distress syndrome & $5(6.6)$ & $2(1.9)$ & $1(0.9)$ & 0.055 \\
\hline Hypoglycemia & $7(9.2)$ & $13(12)$ & $7(6.5)$ & 0.301 \\
\hline Hpototherapy (n) & $19(25)$ & $23(21.3)$ & $14(13.1)$ & 0.104 \\
\hline \multirow[t]{2}{*}{ Phototherapy (das) } & $2(1-7)$ & $2(1-4)$ & $3.1 \pm 1.6$ & 0.05 \\
\hline & & & & ${ }^{\mathrm{c}} 0.048$ \\
\hline \multirow[t]{3}{*}{ NICU need newborn (n) } & $32(42)$ & $38(35.2)$ & $13(12.1)$ & $<0.001$ \\
\hline & & & & $\mathrm{b}<0.001$ \\
\hline & & & & $\mathrm{c}<0.001$ \\
\hline \multirow[t]{3}{*}{ Stay in NICU (days) } & $6(1-13)$ & $6(3-13)$ & $4.2 \pm 2.1$ & 0.042 \\
\hline & & & & $\mathrm{b}_{0.028}$ \\
\hline & & & & $\mathrm{c} 0.015$ \\
\hline Stay in hospital (days) & $8.5(2-30)$ & $8.74 \pm 4.3$ & $5(2-20)$ & $\begin{array}{c}0.015 \\
\mathrm{~b} 0010\end{array}$ \\
\hline
\end{tabular}

Mean \pm SD: Mean \pm standart deviation, $\boldsymbol{n}(\%):$ number (percentage),

M (min - max): Median (minimum- maximum), NICU: Neonatal Intensive Care Unit,

a: $34^{0 / 7}-34^{6 / 7}$ vs. $35^{0 / 7}-35^{6 / 7}$ weeks, ${ }^{b}: 34^{0 / 7}-34^{6 / 7}$ vs. $36^{0 / 7}-36^{6 / 7}$ weeks, ${ }^{c}: 35^{0 / 7}-35^{6 / 7}$ vs. $36^{0 / 7}-36^{6 / 7}$. Oneway-ANOVA test, Post Hoc Tukey-test and bonferroni correction was used for multiple comparisons $\left(\alpha^{*}=0.05 / 3=0.017\right)$.

\section{DISCUSSION}

Late preterm births account for two thirds of all preterm births, and one third of these women present with
$\operatorname{PPROM}^{(14)}$. In our study, late preterm birth rate $(6.7 \%)$ was found to be consistent with the literature ${ }^{(6)}$. During a 3 year period, 85 ( $2 \%$ ) of the 4301 deliveries were in the PPROM group and 206 (4.7\%) were in the group 
that did not develop PPROM. There is no study from our country that investigates late preterm deliveries, but in one study which investigated pregnancies that did or did not develop PPROM before the $34^{\text {th }}$ gestational week found a rate of $3.7 \%$ and $9.6 \%$, respectively ${ }^{(15)}$.

Besides an increase in various neonatal complications in short term such as TTN, RDS, intraventricular haemorrhage, NEC, hypoglycemia, hyperbilirubinemia, neonatal sepsis, and need for NICU, these infants are also at risk for long term complications such as compromised lung function later in life ${ }^{(16-18)}$.

Although we did not observe several severe neonatal complications such as broncho-pulmonary dysplasia, pulmonary haemorrhage and intraventricular haemorrhage in our study, this might be explained by the small sample size and relatively low frequency of these complications, especially in later gestational preterm births.

The RDS incidence in this study were found as $6.6 \%$, $1.9 \%$ and $0.9 \%$ at $34^{\text {th }}, 35^{\text {th }}$ and $36^{\text {th }}$ weeks respectively. Robertson et al. ${ }^{(19)}$ reported the RDS incidences as $13.7 \%, 6.4 \%$ and $3.3 \%$ at $34^{\text {th }}, 35^{\text {th }}$ and $36^{\text {th }}$ weeks respectively in the largest multicentre study conducted so far. This may partially be explained by improvement in NICU facilities during the last 20-year time span between two studies. The higher incidence of sepsis in our study compared to study of Robertson et al. (14.5\% vs. $3.5 \%, 13 \%$ vs. $2.2 \%$, and $3.7 \%$ vs. 1.2 for corresponding gestational weeks respectively) might be explained by possible lower socioeconomic status of our population. RDS, hypoglycemia, hyperbilirubinemia, and neonatal sepsis were the major causes of NICU need and prolonged hospital stay in our study.

Newborns born at $34^{\text {th }}$ and $35^{\text {th }}$ completed gestational weeks were followed up in NICU longer compared to those born at $36^{\text {th }}$ weeks. In addition, the total hospital stay was longer in newborns born at completed 34th weeks compared to newborns born at $35^{\text {th }}$ and $36^{\text {th }}$ gestational weeks in our study. Similarly to our study, Lubow et al. ${ }^{(20)}$ reported NICU stay period as $67 \%$, $30 \%$ and $12 \%$, and the total hospital stay means as $8 \pm 7,3 \pm 4$ and $3 \pm 4$ days for $34^{\text {th }}, 35^{\text {th }}$ and $36^{\text {th }}$ weeks for gestational weeks, respectively.

Microbial pathogens have been reported to be recovered from the amniotic cavity in $10-15 \%$ of the cases with spontaneous PROM and in $32-35 \%$ of women with
$\operatorname{PPROM}^{(21,22)}$. We do not routinely investigate the GBS colonization in our clinic, but, GBS carriage during pregnancy has been estimated to be $10-30 \%$ in most population based on previous studies ${ }^{(23)}$. Transmission of organism to the neonates can occur vertically or, rarely by hematogenous dissemination. More than $98 \%$ of the cases of early-onset GBS sepsis are the consequence of vertical transmission from the genital tract of the mother to the infant ${ }^{(24)}$. Neonatal transmission rate of $60 \%$ had been calculated in one study ${ }^{(25)}$. In line with this, the sepsis rate was significantly higher in newborns delivered vaginally than those delivered by caesarean in this study.

Empiric antibiotic therapy following PPROM reduces risk of neonatal respiratory distress, intra-ventricular haemorrhage and confirmed neonatal sepsis. Cousens et al. ${ }^{(26)}$ were reported a $39 \%$ reduction in incidence of neonatal sepsis (95\% CI 23-52\%, $\mathrm{P}<0.001)$ with antibiotic therapy for PPROM among newborns born following PPROM. Not only PPROM, but also preeclampsia is defined as factors which increase neonatal morbidity in late preterm period ${ }^{(27)}$. Although we have not looked at morbidity rates based on whether or not preeclampsia, 61 of 65 women were in nonPPROM group with preeclampsia.

We analysed only the short-term neonatal morbidity of late-preterm births during the stay of the newborn in the nursery. As stated by Kotecha et al.(18) late preterm infants are at increased risk of respiratory morbidity in the neonatal period with a higher incidence of unavoidable and urgent respiratory interventions, such as mechanical ventilation and treatment with antibiotics, steroids and surfactant for early respiratory infections and insufficiency; thus they may also be at risk of compromised long term lung function later in their lives. Recently, two papers concluded that the burden of prematurity can be decreased if elective late preterm delivery is eliminated, and birth should be considered only if the risk of continuation the pregnancy exceeds the neonatal risks related to early birth $(7,28)$.

In conclusion, although late preterm infants are at increased risk for short and long-term morbidity and possibly mortality and they are also an important burden to the community and they are often not viewed as in high-risk category. However, they deserve a considerable attention and care for increased short and long term complications and mortality rates, which may be costly when overlooked. This study showed that the late- 
preterm infants represent a significantly higher risk category for neonatal complications especially in earlier weeks, and they cause significantly longer NICU and hospital stay periods. In addition, the length of hospital stay increases even more in the presence of sepsis. Vigorous efforts should be put into practice for the detection for early neonatal infectious complications such as colonization and treatment of GBS infections in late preterm deliveries. Delivery should be induced only if risk assesment shows definitive risk in continuation of pregnancy and elective delivery in near term pregnancies should be avoided.

Because of the small number of cases in our study, we could not evaluate the neonatal morbidities according to the gestational weeks. This issue needs to be investigated in a larger patient population.

\section{Conflict of Interest}

We declare that we have no conflict of interest

\section{REFERENCES}

1. Rush RW, Keirse MJ, Howat P, Baum JD, Anderson AB, Turnbull AC. Contribution of preterm delivery to perinatal mortality. Br Med J 1976; 2(6042): 965- 8.

2. AAP, ACOG: Standard terminology for reporting of reproductive health statistics in the United States, in Guidelines for Perinatal Care (ed 5; appendix E). Elk Grove, IL, American Academy of Pediatrics and American College of Obstetricians and Gynecologists, 2002; 377- 94.

3. World Health Organization. Available at: http://www.who.int/ reproductive- health. Accessed June 1, 2005.

4. Engle WA. A recommendation for the definition of "late preterm" (near-term) and the birth weight-gestational age classification system. Semin Perinatol 2006; 30(1): 2- 7.

5. Goldenberg RL, Culhane JF, Iams JD, Romero R. Preterm birth 1. Epidemiology and causes of preterm birth. Lancet 2008; 371(9606): 75- 84

6. Martin JA, Kirmeyer S, Osterman M, Shepherd RA. Born a bit too early: recent trends in late preterm births. NCHS Data Brief 2009; 24: 1 - 8

7. Gyamfi-Bannerman C. Late preterm birth: management dilemmas. Obstet Gynecol Clin North Am 2012; 39(1): 35- 45.

8. Mercer B, Arheart K. Antimicrobial therapy in expectant management of preterm premature rupture of the membranes. Lancet 1995; 346(8985): 1271- 9 .

9. Copper RL, Goldenberg RL, Creasy RK, DuBard MB, Davis
RO, Entman SS, et al. A multicenter study of preterm birth weight and gestational age specific neonatal mortality. Am J Obstet Gynecol 1993; 168:78- 84.

10. Mercer BM, Crocker LG, Boe NM, Sibai BM. Induction versus expectant management in premature rupture of the membranes with mature amniotic fluid at 32-36 weeks: a randomized trial. Am J Obstet Gynecol 1993; 169(4): 77582.

11. Naef RW 3rd, Allbert JR, Ross EL, Weber BM, Martin RW, Morrison JC. Premature rupture of membranes at 34 to 37 weeks' gestation: aggressive versus conservative management. Am J Obstet Gynecol 1998; 178(1): 126- 30.

12. Wigton TR, Tamura RK, Wickstrom E, Atkins V, Deddish $\mathrm{R}$, Socol ML. Neonatal morbidity after preterm delivery in the presence of documented lung maturity. Am J Obstet Gynecol 1993; 169(4): 951- 5.

13. Albayrak M, Ozdemir I, Koc O, Ankarali H, Ozen O. Comparison of the diagnostic efficacy of the two rapid bedside immunoassays and combined clinical conventional diagnosis in prelabour rupture of membranes. Eur J Obstet Gynecol Reprod Biol 2011; 158(2): 179- 82.

14. March of Dimes Perinatal Data Center, "Late preterm birth: every week matters. 2005," National Center for Health Statistics, final natality data, January 2008, http://www.marchofdimes. com/peristats/.

15. Tanir HM, Sener T, Tekin N, Aksit A, Ardic N. Preterm premature rupture of membranes and neonatal outcome prior to 34 weeks of gestation. Int J Gynaecol Obstet 2003; 82(2): 167- 72 .

16. McIntire DD, Leveno KJ. Neonatal mortality and morbidity rates in late preterm births compared with births at term. Obstet Gynecol 2008; 111(1): 35- 41.

17. Shapiro-Mendoza CK, Tomashek KM, Kotelchuck M, Barfield W, Weiss J, Evans S. Risk factors for neonatal morbidity and mortality among "healthy," late preterm newborns. Semin Perinatol 2006; 30(2): 54- 60.

18. Kotecha SJ, Dunstan FD, Kotecha S. Long term respiratory outcomes of late preterm-born infants. Semin Fetal Neonatal Med 2012; 17(2): 77-81.

19. Robertson PA, Sniderman SH, Laros RK Jr, Cowan R, Heilbron D, Goldenberg RL et al. Neonatal morbidity according to gestational age and birth weight from five tertiary care centers in the United States, 1983 through 1986. Am J Obstet Gynecol 1992; 166(6): 1629- 41.

20. Lubow JM, How HY, Habli M, Maxwell R, Sibai BM. Indications for delivery and short-term neonatal outcomes in late preterm as compared with term births. Am J Obstet Gynecol 2009; 200(5): e30- 3. 
21. Kenyon SL, Taylor DJ, Tarnow-Mordi W; ORACLE Collaborative Group. Broad-spectrum antibiotics for preterm, prelabour rupture of fetal membranes: the ORACLE I randomised trial. ORACLE Collaborative Group. Lancet 2001; 357(9261): 979- 88 .

22. Kenyon SL, Taylor DJ, Tarnow-Mordi W; ORACLE Collaborative Group. Broad-spectrum antibiotics for spontaneous preterm labour: the ORACLE II randomised trial. ORACLE Collaborative Group. Lancet 2001; 357(9261): 98994.

23. Centers for Disease Control and Prevention. Prevention of perinatal group B streptococcal disease. Revised guidelines from CDC. MMWR Recomm Rep 2002; 51(RR-11): 1- 22.

24. Klein LL, Gibbs RS. Use of microbial cultures and antibiotics in the prevention of infection-associated preterm birth. Am
J Obstet Gynaecol 2004; 190(6): 1493- 502.

25. Namavar Jahromi B, Poorarian S, Poorbarfehee S. The prevalence and adverse effects of group B streptococcal colonization during pregnancy. Arch Iran Med 2008; 11(6): 654- 7.

26. Cousens S, Blencowe H, Gravett M, Lawn JE. Antibiotics for pre-term pre-labour rupture of membranes: prevention of neonatal deaths due to complications of pre-term birth and infection. Int J Epidemiol 2010; 39(1): i134- 43.

27. Masoura S, Kalogiannidis I, Margioula-Siarkou C, Diamanti E, Papouli M, Drossou-Agakidou V. Neonatal outcomes of late preterm deliveries with preeclampsia. Minerva Ginecol 2012; 64(2): 109- 15.

28. Chescheir N, Menard MK. Scheduled deliveries: avoiding iatrogenic prematurity. Am J Perinatol 2012; 29(1): 27- 34. 